Volume 5, Issue 2

September 2012

\title{
Space-age Hornblowers, or why Kirk and co. are not space cowboys: The Enlightenment mariners and transatlanticism of Star Trek
}

\author{
STEFAN RABITSCH, Alpen-Adria-Universität Klagenfurt (AAU)
}

\begin{abstract}
Many mistakenly perceive Star Trek to be, simply, a "Wagon Train to the stars," a space western/opera that projects the U.S. American frontier into outer space. However, by introducing his starship captain in archetypal terms as a 'space-age Captain Horation [sic] Hornblower,' and by making him a descendant of 'similar [naval] men in the past,' Star Trek (1966-1969) creator Gene Roddenberry makes it clear that his starship captain is not based on the quintessential cowboy hero found in the U.S. American national imagination (Roddenberry, 1964: 5). In this article, I seek to (re)map the character contours of the principle Star Trek captains and compare them with C. S. Forester's 'man alone,' Horatio Hornblower, as well as with Hornblower's romanticised predecessors. I will demonstrate how 'Starfleet's finest' fit the role of the sentimental naval officer/hero of the Romantic period. Ultimately, it will become clear that Roddenberry used Horatio Hornblower as an archetypal blueprint to craft the Star Trek captains as interstellar masters and commanders, as well as spaceborne naturalists and scientists, extending the historio-mythical continuum of British maritime heroes into Star Trek's fictional, yet "historical" future. The "Hornblowers in space" represent the central node in the decidedly transatlantic double consciousness of the Star Trek continuum - a maritime endowment which has largely escaped scholarly attention.
\end{abstract}

\section{KEYWORDS}

British maritime fiction, C. S. Forester, Gene Roddenberry, Hornblower, Nelsonian heroes, Science Fiction, Star Trek, Telefantasy, transatlanticism.

\section{Introduction: Sailing, not riding, into an unknown future}

When Captain Kirk attempts to understand why an alien species, intent on ascertaining humanity's moral trajectories, has his intrepid away team re-enact the Gunfight at the O.K. Corral, he concludes that it is 'because my ancestors pioneered the American frontier' (Star Trek: The Original Series 3.06, 'Spectre of the Gun'). Such an assertion seems only appropriate in a Science Fiction continuum which was originally pitched as 'Wagon Train to the stars' and whose iconic opening narration is deeply couched in John F. Kennedy's 'New 
Volume 5, Issue 2

September 2012

Frontier' rhetoric (Roddenberry, 1964: 3). Star Trek's (1966-1969) 'final frontier' is the Science Fictional descendent of the president's New Frontier, in that he used it to refer to more than simply the American conquest of outer space. It is to be understood as a metaphoric space which is 'sufficiently mobile to signify across real and imagined geographies' (Monteith, 2008: 19). It is powerfully wrapped in the myth of the Old West, onto which the hopes and fears, and the pertinent issues of the day were projected (cf. Abbott, 2006: 23-25, McCurdy, 1997: 91-97, 139-141). However, Star Trek ${ }^{1}$ only sparsely refers to the frontier master narrative as it is popularly entertained by the U.S. national consciousness. Episodes such as the one quoted above are the exception, indeed an aberration, rather than the rule (ST:TNG 5.26, 'Time's Arrow;' 6.01, 'Time's Arrow, Part II;' 6.08, 'A Fistful of Datas;' ST:ENT 3.09, 'North Star'). Moreover, it is an often overlooked fact that the TV Western, Wagon Train (1957-1965), provided the blueprint for Star Trek only so far as it was an example of a television show format which featured a regular cast, and which could also serve as a vehicle for guest-stars (Yoggy, 1996: 175-176). Furthermore, Star Trek's thematic accommodation of Kennedy's New Frontier appropriates little more than the metaphoric qualities of the frontier as an imagined space onto which the grand spectacle of the human condition may be projected, drawing from ever-changing U.S. socio-cultural contexts (cf. Rabitsch, 2011).

Yet, there is a second, largely unacknowledged thematic presence in Star Trek which draws on the transatlantic significance of the British Golden Age of Sail (cf. Black, 2004: 14-15, Fernández-Armesto, 2007: 10-15). Star Trek was also pitched as 'Hornblower in space' (cf. Roddenberry, 1964: 5, Gerrold, 1973: 218). Initially only referring to the show's lead character, the phrase hints at a historio-mythical substance that Star Trek draws upon, similar to those sentiments engendered by the motto 'Rule, Britannia' (enshrined in James Thomson's and David Mallet's 1740 song of the same name (Gregg, 2005: 87-88)). It is a nautical endowment which manifests itself along five interrelated maritime dimensions, which range from 1) nautical jargons of naval hierarchies, power projection and maritime exploration, 2) the starship as a re-imagined wooden ship-of-the-line that is 3) captained by the transposed sentimental naval officer/hero of the Romantic period, to the practice of 4) nautical traditions and the presence of naval intertexts, which are set against the future backdrop of 5) a benignly imperial, interstellar Golden Age of Sail. The 'Rule Britannia' theme implies a transatlantic double consciousness which celebrates an Anglophone cultural continuum transposed into a fictional, yet 'historical' future. As Lincoln Geraghty asserts, 'Star Trek's clever use of familiar symbols and tropes... reproduces a historical narrative' (Geraghty, 2007: 29). But not only does Star Trek's assumed historicity apply to its appropriation of the Puritan American Jeremiad (which is central to Geraghty's study (Ibid.: 68-85)), but also to Star Trek's nautical endowment which draws on the British Golden Age of Sail.

Star Trek's nautical endowment has attracted the attention of only a few scholars. Due to their different approaches, their forays, though well-founded, remain limited in their scope in 
Volume 5, Issue 2

September 2012

that they neglect the complexities which a transatlantic cultural continuum brings to Star Trek stories. In some respects, they are also incomplete since they are distracted by American surfaces, both literally and metaphorically, without drawing too much on the 'Rule Britannia' theme which is abundant. Michèle and Duncan Barrett ask the question how much of Hornblower can be found in Star Trek's captains. However, they do not move beyond the generic elements that hold for almost any sea captain (Barrett, 2001: 41, 43-47). Not only do

they draw on non-canonical sources to underscore some of their points, ${ }^{2}$ but they also link Star Trek's 'nautical metaphor' to 'the historical literature of American maritime supremacy' (Ibid.: 12, 19). Jonathan Rayner also acknowledges the nautical presence of Hornblower but asserts that 'the model of eighteenth- and nineteenth-century European imperialist voyages seems inapplicable' because he sees 'the entirety of US naval history' as a 'common frame of reference' (Rayner, 2007: 159, 153). I intend to build on this pre-existing critical work, but I will also expand on it - particularly by drawing more on the Hornblower novels, and other relevant British maritime heroes, to illustrate crucial aspects which made Roddenberry liken his future to the Golden Age of Sail (cf. Roddenberry, 1967: 23, Whitfield and Roddenberry, 1991: 179, Gerrold, 1973: 11).

Ultimately, even the opening narration of Star Trek may be (re)read along nautical/transatlantic lines when its 'to boldly go where no man [one] has gone before' is juxtaposed with one of the most widely quoted passages in the journals of Captain Cook, 'whose ambition [led him] not only farther than any other man ha[d] been before [him], but as far as [he thought] it possible for man to go' (Edwards, 2003: 331). Consequently, the Starfleet captains are revealed to have a vastly different literary ancestry than that which erroneously connects them to the quintessential frontier cowboy, and it is they who represent the central node in Star Trek's decidedly transatlantic double consciousness.

\section{'Fighting naturalists' in space}

Nowhere is the purposefully rendered maritime endowment by the mythologised British Golden Age of Sail more visible than in the archetypal make-up of Star Trek's principle Starfleet captains, as they slip into the iconic role of the sentimental naval officer/hero of the Romantic period. Theirs is a Hornblower-type of sentimental heroism, sharing a specific set of traits and behaviors with two of the quintessential representatives of maritime exploration and military might - Horatio Nelson and James Cook. Consequently, Starfleet captains, as agents of an imperial enterprise, benign as they may profess it to be, are the genealogical descendants of those Joseph Conrad labeled the 'fathers of militant geography' (O'Sullivan, 2008: 99). Still, their portrayal is mostly devoid of the unpleasant sting of moral accusation in the light of Star Trek's purportedly more enlightened, historical future. They are modeled only on the romanticised personae of these naval heroes and do not necessarily draw on historical actualities. 
Volume 5, Issue 2

September 2012

In order to illustrate both the vast range of functions that British naval officers, as mariners of the Enlightenment fulfilled, ${ }^{3}$ and how they became condensed into the character of the Starfleet captain, it serves to employ a telling descriptor. In the movie adaptation of Patrick O'Brian's novel The Far Side of the World (1984), ${ }^{4}$ a young midshipman, after having been seriously wounded, muses about the compatibility of military duty and scientific ventures as they are represented by the main protagonists, Captain Jack Aubrey (Russell Crow) and the ship's surgeon, Stephen Maturin (Paul Bettany). The midshipman resolves that he could pursue both and become a 'fighting naturalist.' Similarly, "Hornblower in space" is television shorthand for describing a process of adaptation and extrapolation which results in Starfleet captains acting as 'fighting naturalists' in outer space. Roddenberry used Hornblower as a paradigmatic blueprint to craft the archetypal Starfleet captain by equipping him with the universally mythologised qualities of the two most widely remembered naval officers of the Golden Age of Sail (Nelson and Cook). Thus, 'Hornblower in space' incorporates the mythologized attributes of the Romantic naval officer/hero, and those of Hornblower.

What emerges is a character formula which represents a particular permutation of the attributes and circumstances that hold true for any sea captain. This includes their solitary existence, which is determined by their hierarchical distance from their men, as well as their geographic isolation from their homeland, and their seemingly divine powers governing every aspect of the lives entrusted to them. Forester conceived of his hero as "a man alone" somebody who, despite being revered instead of feared by his men and despite allowing for open communication and complete trust among his "band of brothers," ultimately bears sole responsibility for his decisions. Driven by innate zeal, he is prone to take the initiative and to use his common sense not only to go beyond his orders but also to question, and sometimes even to defy them if he deems it necessary to achieve the successful outcome of his mission. His advancement by merit rests on a paradox which is coupled to a lack of political ambition. All he wants to do is to be in command of a ship but his successes may lead to a promotion which, in turn, takes him further away from the profession he prefers. This preliminary sketch of the Hornblower archetype would not be complete without a general lack of domestic happiness as well as an incessant psychological struggle that is shaped by self-criticism, selfdoubt and the loneliness of command.

Narratively, the "Horatio"-part of Roddenberry's descriptor is also significant. It symbolically installs the onomastic meanings which led C. S. Forester to name Hornblower after Hamlet's loyal friend (Forester, 1998: 90). It translated into Hornblower becoming the teller in the heterodiegetic narrative of the novels. By the same token, Starfleet captains are charged with the role of being chronicling narrators via their captain's log. The log is both a naval tradition, and a historical archive which is used to record a "history of the future."

Not only is the following character study an exercise in tracking and understanding the hybrid character of the naval warrior and the naval explorer, and how it entered the Star Trek continuum, but it is also a study of variants and variations. Over the course of almost fifty years of Star Trek on television and on film, none of the five principle Starfleet 
Volume 5, Issue 2

September 2012

captains appear to be alike. Yet, as Geraghty convincingly argues, Star Trek stories rely on only a few 'foundational narratives,' which are continuously shaped and reshaped by changing socio-political contexts of production to present a seemingly infinite number of narratives (Geraghty, 2007: 27). The same holds true for the 'Hornblower in space' archetype since, despite their perceived differences, none of the five principle captains break the basic character formula as outlined above. In fact, this label can be applied to seven captains (due to Star Trek's peculiar beginnings). In Roddenberry's first pitch for ST:TOS, the captain's name is Robert M. April (Roddenberry, 1964: 5). He does not appear on-screen, except for a brief guest appearance (voiced by James Doohan) in one episode of ST:TAS. ${ }^{5}$ The first actor to assume the role of 'Hornblower in space' was Jeffrey Hunter, who portrayed Captain Christopher Pike in the first Star Trek pilot episode (1.00, 'The Menagerie,' later re-titled 'The Cage'). The pilot was rejected by television executives and censors. However, in an unprecedented move, Roddenberry was given a chance to produce a second pilot, in which the leading actor was replaced. The initial pilot did not air until 1988 and, even though it is but one episode, it provides sufficient material featuring the captain to be pertinent to this character study. Hence, references to Captain Pike will be woven into the mapping of the archetype where appropriate. ${ }^{6}$ Pike can be seen as a test-run of the 'Hornblower in space' archetype before its first full articulation, Captain James T. Kirk (William Shatner).

The five main Star Trek captains are best introduced along maritime terms in an impromptu taxonomy. These preliminary profiles are not exhaustive since they only outline certain key aspects of how particular attributes of the archetype manifest themselves more in one captain than the other. Moreover, they may also be viewed as particular stages in Hornblower's picaresque growth as a character. Consequently, Captain Kirk can be seen as a naval swashbuckler since he is more of an action-adventure type of hero. He tends to rush into taking the initiative faster than his fellow captains. Kirk is reminiscent of Hornblower when the latter achieves post-rank and during the first years of his captaincy (Forester, 1937; 1938; 1953). In ST:TNG, Captain Jean-Luc Picard (Patrick Stewart) epitomizes the naval stargazer who, despite being on a broad mission of exploration, finds himself proving his diplomatic finesse in countless negotiations, involving many different parties. This mirrors Hornblower's growth in maturity when he is given his own squadron and dispatched to the Baltic, and later to northern France to deal with a political/military situation on a European scale (Forester, 1945; 1946). Upon assuming command of the station Deep Space 9 in the eponymous series, Commander (later Captain) Benjamin Sisko (Avery Brooks) takes the post in the vein of Hornblower when the latter is transferred to the West Indies (Forester, 1958). Operating from a stationary habitat, he is a naval commander-in-chief deeply entrenched in the realpolitik of interstellar exploration, politics, commerce and a conflict whose outcome affects billions of people. As with Hornblower, Sisko's moral integrity and his conscience are put to the test more than once. ST:VOY has Captain Kathryn Janeway (Kate Mulgrew) embarked as a naval pathfinder on a journey of Odyssean proportions when she finds herself stranded and lost on the other side of the galaxy. She finds herself nurturing a small family of 
Volume 5, Issue 2

September 2012

intrepid adventurers pursuing a single goal - to return home. The journey is marked by her making many hard choices which, however, do not preclude her from making new discoveries along the way. ST:VOY appears almost as a conflation of Hornblower's independent cruise in Pacific waters and his long journey home as he affects an escape from hostile territory with a crew of two (Forester, 1937; 1938b). Finally, in ST:ENT, a prequel show, Captain Jonathan Archer (Scott Bakula) clears the moorings of spacedock as a naval naïf. Like Captain Cook, who was among the first to comprehensively chart the vastness of the Pacific, Archer is struck by the wonder of it all. His reverie of deep space exploration quickly gives way to a need to grow in command maturity, and proves to be a baptism by fire. To some extent, Archer's growth mirrors Hornblower's as the latter learns his first valuable lessons at command as a young midshipman. He grows increasingly adaptable when he becomes involved in the exigencies of command when he advances to the rank of lieutenant (Forester, 1950; 1952). Even though certain character traits and behaviors are emphasized from one captain to the other (according to the particularities of the respective captain's mission or situation), they do not move beyond their archetypal character constraints. This secures the comfort of familiarity on the part of the audience, without endangering archetypal coherence. And, echoing James Cook, the broad mission statement 'to boldly go where no one has gone before' can be applied to all captains.

Based on a comparison of Hornblower's distinct attributes, taken directly from the novels and C. S. Forester's notes, with relevant echoes of them found in all principle Starfleet captains, I will demonstrate how the character of the starship captain has essentially remained the same throughout the entire Star Trek continuum. Before examining how the ways in which this archetype has been re-articulated, however, it is necessary to look at the mythologised personae of Nelson and Cook in order to understand how they have been subsumed under the descriptor of 'Hornblower in space'.

\section{Palmam qui meruit ferat ${ }^{7}$}

Horatio Nelson's motto, as found on his coat of arms, acts as a leitmotif for a military service, in which - despite all class restrictions - men of modest, even impoverished circumstances could elevate their social status by relying on their own devices (Czisnik, 2005: 8). This is definitely true for Nelson and Cook, who both excelled in their profession as versatile maritime agents of an imperial project; the former exhibiting considerable zeal and desire for command, the latter significant professional ambition and intrepidity. The meritocracy presumably found in the Royal Navy of the Golden Age of Sail also provides the picaresque template for the large bulk of sea novels which have been published since the early 19th century. They embodied the opportunity to move from before the mast to the quarterdeck, and in rare cases - as happened with Hornblower - even gain a peerage (Parrill, 2009: 11). The Cook(s) and Nelson(s) of history and fiction oscillate between acknowledging 
Volume 5, Issue 2

September 2012

the worth of individuals and imposing various forms of disciplinary forces on said individuals.

These maritime archetypes are perceived and remembered by their own men as well as the popular imagination as being different from many of their contemporaries in that they appeared to be fairer and more humane in a brutal seaborne world. The trust they inspired among those who were under their command fostered early precursors to modern command culture since they allowed for clear and open communication of orders, delegation of responsibility, and suggestions from their subordinates (cf. Vincent, 2005: 94-99, White, 2005: 53-57). Ultimately, these Nelsonian heroes were mythologised into the embodiment of British Romantic sentiment and the ideal(ised) British gentleman (cf. Harris, 2006, Fulford, 1999). Though aware of historical inaccuracies and contradictions in the mythologising processes of both Nelson and Cook, this character study is largely informed by the most popular and widely remembered representations, and their fictional descendants. Early on, they emerge in elegies, paintings, monuments, songs and theater productions. Their personae are nurtured chiefly by their most influential biographers whose works were tapped into by writers, advertisers and filmmakers (cf. Czisnik, 2005: 97-100, 134-140, O'Sullivan, 2008: 415, Parrill, 2009: 289-301). In film and television, Nelson is portrayed, for example, in That Hamilton Woman (1941), The Nelson Affair (1973) and the 4-part series I Remember Nelson (1982). Cook's voyages were made into the mini-series Captain James Cook (1987) and his exploits were enshrined in number of documentary films. Many of these artifacts illustrate a composite archetype, i.e. the Enlightenment mariner, who, as introduced above, rests on a shared set of characteristics and behavioral patterns. Horatio Hornblower was conceived in the same vein.

The mythologisation of Nelson, which began in the immediate aftermath of his death at Trafalgar (1805), led to an apotheosis, turning him into "the first British "pop hero"' (White, 2005: 68). The main model for the Nelson myth was provided by his first biographer, Robert Southey, and has been reiterated in umpteenth permutations since. Southey depicts Nelson as 'checked by piety and humanity,' displaying 'interest in, and care for, his subordinates' as well as 'constancy in his friendships and agreeable personal manners,' 'intelligence' and 'professional ability' (Czisnik, 2005: 87). He constructs Nelson as 'lovable as well as admirable' and creates the impression that readers 'would vicariously enjoy being under his command' (Fulford, 1999: 173). Nelson is driven by 'enormous zeal' and an ambition for 'high achievement in his chosen profession' (Czisnik, 2005: 84). He is bold and courageous but he is not fearless. His focus on professional achievement frees him to increasingly rely on his own judgment to make decisions, critically interpreting his superiors' orders. Czisnik asserts that the Nelson of the popular imagination is prone to make 'decisions that were uncomfortably independent of those taken by his superior[s]' (Czisnik, 2005: 17-18). This is commonly used to equip Nelsonian heroes with an archetypal propensity to question and also to go beyond their orders. 
Volume 5, Issue 2

September 2012

Nelson's ambition and professional zeal were neither driven by fear nor by an excessive lust for power beyond his own command (Czisnik, 2005: 85-86). Hence, he is also not inscribed with any significant political ambitions; another key characteristic of the Enlightenment mariner. Instead of employing his military success to enter politics, 'Nelson cast himself as a hero, an instrument at the disposal of his king and country' (Vincent, 2005: 76). Once a certain level of success has been achieved - usually the captaincy/an independent command the Enlightenment mariner becomes weary of further advancement.

The persona of Captain James Cook, as it is readily entertained in popular culture, is also a product of a mythologising process of more than 200 years. The archetypal naval explorer is conceived in terms which ultimately imply a distinct similarity to the archetypal naval warrior. Cook is commonly perceived as 'a legendary figure, a hero of the Enlightenment, who was said to have brought civilization to the Pacific' and as 'a master voyager who journeyed to unknown places, a seeker of knowledge' (O'Sullivan, 2008: 1). Driven by a high degree of professional ambition and intrepidity, he was 'undoubtedly rugged and powerful, yet with a certain hint of introspection, even sadness' (Ibid.: 7). He is cast not only as a benign and benevolent commander and discoverer, but he also shows a degree of introspection, which is congruent with the tendency to imbue Enlightenment mariners with a troubled psyche (Ibid.: 39). The Cook(s) and Nelson(s) of fiction go to great lengths to contemplate their decisions, not only to justify them for themselves but also to provide good reasoning for vindicating their actions. In the same vein, Cook has been idealised as 'a heroic figure... who seldom puts a foot wrong' (Ibid.: 51). The Cook of popular culture is essentially a working class hero.

Cook also develops a command style and a stance on how to 'interpret' his orders which is similar to Nelson's (and Hornblower's). Cook articulated the way he understands orders in a letter to a young French explorer in which he states that, 'I maintain that someone who only obeys orders will never make a name for himself as a discoverer' (O'Sullivan, 2008: 11). There is no doubt that he also displays a distinct propensity to go beyond the purview of his original orders. For example, instead of simply ascertaining the existence of the mysterious southern continent, as the classified orders for his first journey specified, he went ahead and claimed the entire east coast of Australia for the British Crown as soon as he had concluded that it must be the elusive Terra Australis.

The meritocratic James Cook of the popular imagination has a reasonably lucid understanding of how to handle his officers, his crew and the supernumeraries on his voyages. Commenting on his leadership skills, Glyndwr Williams singles out 'his sense of when discipline must be rigidly enforced and when it might be relaxed' (Williams, 2004: 232). There are a number of occasions in his journals which allow for parallels to be drawn with the Nelsonian 'band of brothers' paradigm. Cook's command style, which presumably grew out of necessity and the ambition to succeed at his missions, can be seen as a precursor of what would later be termed the 'Nelson Touch' since he 'relied on his officers to take decisions' (O'Sullivan, 2008: 83). Cook is also represented as a much respected, even 
Volume 5, Issue 2

September 2012

revered paternal figure, especially to a group of midshipmen and master's mates (Ibid.: 86). Ultimately, 'this stern, secretive disciplinarian came to be held in great affection as well as awe by his brother officers,' and thus 'admiration for his qualities as commander and explorer is rarely in doubt' (Ibid.: 85, my emphasis).

James Cook, much like Horatio Nelson, is portrayed as being different in his display of below average cruelty and above average benevolence and patience towards both his crew and the score of indigenous peoples he came in contact with. It goes without saying that this portrayal is highly distorted and historio-mythically misrepresented, since Cook is commonly compared to his seemingly more avaricious Spanish predecessors as well as his French and even British contemporaries. Still, Cook was as much a vector of imperial power projection as the others, and the British imperial enterprise was anything but benign (O'Sullivan, 200: 137-139, Lamb, 2006: 101-103). Since his death at the hand of an indigenous Hawaiian, the captain has been perennially eulogized as 'the mild hero' and 'the emissary of "humanity", (Williams, 2008: 67).

It is beyond doubt that both Nelson and Cook were 'floating agents' of the British Empire; both were vectors of power projection, the one surveyed and took possession of alien spaces whereas the other defended British sentiments and interests against a continental tyranny. Williams reductively observes that though ' $[\mathrm{m}]$ embers of the same service Horatio Nelson and James Cook had little in common except the respect of their superiors and the affection of their crews' (Williams, 2004: 235). Indeed, as it has already been established, they are representatives of two distinct yet interrelated fields - maritime military might and maritime exploration. Yet, the way both naval heroes are commonly remembered and represented makes it clear that they share many more characteristics as sentimental(ised) heroes of British romantic thought. Continuous mythologisation and fictionalisation have installed this archetype of a captain as 'a floating signifier' which transcends the imagined borders of British Romantic thought (O'Sullivan, 2008: 230). This character has achieved a life of its own which is both independent from historical actualities and yet still tethered to the imperialist discourse of the British Golden Age of Sail. Still, it has become sufficiently disentangled from any one particular national discourse so that it may be transferred across imagined cultural borders. It was picked out of the water of a transatlantic imaginarium by $\mathrm{C}$. S. Forester and sent on its way in the form of Hornblower, who soon found himself cast loose on an ocean of space.

\section{The man alone: A transatlantic hero heads into outer space}

The immediate socio-cultural context, which formed the nurturing transatlantic basis for C. S. Forester's Hornblower novels, ${ }^{8}$ and Roddenberry's exposure to them, was as much determined by the prologue to, and outbreak of, World War II, as it was subjected to largescale politico-cultural shifts of power and influence within the Anglophone sphere. Forester was in the vanguard of bringing the British sea novel into the 20th century on a considerably 
Volume 5, Issue 2

September 2012

larger, transatlantic scale. The Hornblower novels, especially the first four installments, were favourably received on both sides of the Atlantic, which ultimately transformed his hero into a common transatlantic symbol. Hornblower's exploits were first published in serialized form in the Saturday Evening Post and other periodicals, such as Collier's Magazine and Argosy in the late 1930s and early 1940s. These media outlets ensured that millions of Americans were introduced to an archetypal British character, the sentimental gentleman Navy officer/hero of the Romantic period, who is deeply invested in and imbued with the legacy of the Golden Age of Sail. The stories also drew Forester into the propaganda machineries of the Navies on both sides of the Atlantic (Sternlicht, 1999: 34-35, 159-160; Forester, J. 1997: 540-51). Hornblower was Forester's attempt to do 'everything he possibly could to bring Britain and America closer toward a cultural harmony and a closely related identity' before, during and after World War II (Sternlicht, 1999: 16). He also decided on July 4, 1776 as his hero's date of birth; a potent symbolic act (Forester, 1950: 13). Even the hero's name is itself a product of transatlantic discourse, born out of Forester's largely transatlantic life. For a time, he traveled back and forth - by ship - from California to Britain (Sternlicht, 1999: 16, 31-35) and the name Hornblower derives from Forester's producer in Hollywood, Arthur Hornblow Jr. (Sternlicht, 1999: 33). According to Forester, the name Horatio did not derive from his obvious namesake Horatio Nelson. It 'met an essential requirement' and had 'contemporary associations' but ultimately, it stems from Hamlet's loyal friend (Forester, 1998: 90). Horatio, as the narrator in the novels, acts upon the etymological substance of his name.

Based on an interview shortly before Gene Roddenberry's death in 1991, his biographer, David Alexander, notes that Hornblower was 'without question, Gene's favorite literary character, he read Hornblower when it was first published in the United States in 1939 and continued to reread the novels until a few weeks before his death' (Alexander, 1994: 188). Hornblower was the central point of reference in Roddenberry's first sketch of the archetypal Starfleet captain (Roddenberry, 1964: 5). What those who have already engaged with some of the manifold nautical elements in Star Trek neglected to draw on is another passage on the same page in which Roddenberry establishes a link 'with similar men in the past' (Ibid.). The distinguished names he lists reverberate with telling significance: Sir Francis Drake, Captain James Cook, Admiral Louis Antoine de Bougainville and Captain Robert F. Scott. The archetypal Starfleet captain would then be fully defined and articulated in Hornblower-esque terms in the first two incarnations of Star Trek (ST:TOS, ST:TNG), then historicised as an established archetype, the character 'blueprint,' in the later shows.

Hornblower is cast in the vein of Enlightenment mariners as outlined above. The very core of their characters, as they pursue the vastly diverse missions they are assigned by the Admiralty, is a result of their continued exposure and reaction to spatial, temporal, hierarchical, psychological and emotional isolation and/or detachment. C. S. Forester delineates this archetypal character trait of his hero as follows: 
Volume 5, Issue 2

September 2012

The man who has to make unaided decisions. The man alone; he may have technical help, he may even have friends, but as regards the crisis he is facing he can only act on his own judgment, and in case of failure he has only himself to blame. This Man Alone - the captain of a ship. (Forester, 1998: 82)

The multifaceted isolation and detachment, which is based in a set of orders, has been central to the format of Star Trek's spaceborne adventures since the earliest draft for the first series. Later, Roddenberry defined his status as a 'man alone' in much greater detail in the guide for writers/directors for ST:TOS. His character description equally applies to Captain Pike as well as to Captain Kirk. A commanding officer who,

with the Starship out of communication with Earth and Starfleet bases for long periods of time, [has] unusually broad powers over both the lives and welfare of his crew, as well as over Earth people and activities encountered during these voyages. He also has broad power as an Earth Ambassador to alien societies in his galaxy sector or on new worlds he may discover. (Roddenberry, 1967: 10)

In a section of his guidelines titled 'some questions and answers,' Roddenberry even goes so far as to answer the question whether the mission of the Enterprise was not similar to 'English warships' during the Age of Sail. He explicitly states that,

in those days [...] the captains of such vessels had broad discretionary powers in regulating trade, bush wars, putting down slavery, assisting scientific investigations and geological surveys, even to becoming involved in relatively minor items like searching for a lost explorer or school mistress. (Ibid.: 27).

Even though they are a part of a 'semi-military' service (Starfleet) and, thus, belong to a large, seemingly colonial network of vessels and bases, shaped by a naval discourse, Roddenberry makes it particularly clear 'to keep Kirk and the Enterprise far away and out of touch' because it allows writers to easily create moments of dramatic decisions for the captain (Ibid.: 24-27). This is the same type of drama that C. S. Forester uses as a mainstay in his novels where Hornblower is left to his own devices in trying to ensure the best possible outcome for any situation in which he might find himself (Sternlicht, 1999: 32). His conduct, his decisions and their outcome would then hopefully exonerate him in the eyes of his superiors. After all, the captain has 'to conduct his ship according to the spirit and letter of his orders by means of his own initiative and interpretation' (Ibid.). As Kirk and his crew 'have passed into history... and are known as legends throughout the Federation' (Roddenberry, 1987: 3), they are evoked to historicise the fictional future of Star Trek (Star Trek:

Generations (1994); ST:DS9 5.06, 'Trials and Tribble-ations;' ST:VOY 3.02, 'Flashback'). By the time Roddenberry died, the archetype of the Starfleet captain, as informed by Hornblower, had been firmly established. Hence, the mission for Captain Picard largely 
Volume 5, Issue 2

September 2012

remains unchanged. Since the captain is always 'the leading man and central character' (Roddenberry, 1964: 5), the "man alone" trope would not be radically changed by his successors.

It is the situations of detachment and the degrees of isolation that would change in the later series. They would also shift some of the emphasis on different aspects of the archetype (without ever really changing the basic model). Hence, when Commander Sisko takes command of Deep Space 9, located at the very periphery of the Federation, it is represented as an exotic port of call, reminiscent of Hornblower's station in the West Indies, and where the transience of alien multitudes and local color form leitmotifs. His mission is essentially colonial in that he is 'to spearhead the arduous diplomatic and scientific efforts that accompany the lengthy entry procedure' of a local alien society into the Federation (Berman et al., 1992: 3-5). Though Sisko is in contact with the higher echelons on Earth more regularly (as is Hornblower in the Caribbean), over the course of his mission, he repeatedly finds himself, as prescribed by the archetype, in situations where his resolve provides the decisive weight. At this point, the writers and producers dispense with reiterating the responsibilities and the power of the captain since the Hornblower archetype had become the accepted norm in the Star Trek continuum. They do not explicitly restate the descriptor in the series bibles because the manner in which the protagonist captain functions is apparently understood as a given. The fighting naturalist in outer space has become the norm.

When Captain Janeway finds herself hurdled to the other side of the galaxy, she is instantly placed on the most detached and independent cruise of all the captains. She has no support structure except for her crew, and she is wholly dependent on her own judgment, taking the responsibilities borne by the archetype to a new level (Berman et al., 1995: 1). Still, the Captain is adamant about upholding the principles of Starfleet and she intends to "continue to go boldly, to explore, study, and investigate' (Ibid.: 2). Despite or, rather, because of the fact that $S T: E N T$ is a prequel show - set roughly 100 years before ST:TOS - Captain Archer finds himself very much detached from Earth since he is not only Starfleet's first deep space explorer but also the face of humanity as he acts as an ambassador on the interstellar stage. There is a pronounced excitement about being and/or going first which recalls a similar sentiment shared by Captain Cook (Fernández-Armesto, 2006: 291). Still, by being and going first, his decisions bear a distinct significance because they set benchmark for later generations of captains (Berman et al. 2001), staying true to the archetype 'he has a strong sense of duty, he's a bit of a renegade - he is not afraid to question orders or even disobey them, if he feels in his gut that he's right' (Ibid.). Hence, the archetypal premise of 'the man alone' as it is provided by Hornblower can be observed in all of his descendants, on their respective distant stations in outer space.

\section{"Don't let them promote you": The paradox of success}


Volume 5, Issue 2

September 2012

Being a captain, whether at sea or in space, making all the decisions, and bearing the sole responsibility for them, inevitably creates a troubled psychological profile. However, the desire to remain in a position of independent command presents the central paradox of the archetype. Since the Hornblower novels follow the generic picaresque formula of the sea romance, this paradox is rooted in the meritocratic rise of the hero which turns into a meritocratic anxiety once the rank of 'post captain' has been attained (Parrill, 2009, 8-14). Conceived in the vein of the fear about the anti-climax - the journey is the destination - and merged with a lack of interest in politics on part of the meritocratic protagonist, the romanticised Enlightenment mariner tries to keep the uneasy equilibrium of being a successful captain at sea, staying on an independent cruise. Historically, to attain the rank of post captain was the goal of most young men in the Royal Navy because once reached, they would enjoy a degree of "job security" and a guaranteed rise through the ranks based on their years of service, becoming admirals, being knighted or even receiving a peerage. Yet, this would inevitably bring them closer to home and involve them in the political machinations of the land.

Price accurately asserts that once Hornblower had become more mature as a commanding officer 'he would rather be a captain and poor than anything else and rich' (Price, 1992: 146). Forester puts forth that 'Hornblower was never a man to know complete happiness... [and despite] his peerage and his flag... though mellowed he would not lose his old restlessness, his desire for action, his quickness of thought' (Forester, 1998: 126). It is much more clearly articulated by Hornblower himself once he has been made a knight of the Order of the Bath and consequently tries to steer clear of the political echelons which never seem to be far away for someone whose second marriage is to the fictional sister of the Duke of Wellington (Forester, 1938b: 148-155; Forester, 1945: 164; Forester, 1946: 444, 451, 486-489). Hence, it is not surprising that Roddenberry also insisted that his starship captains are to 'stay away from petty military politics' (Roddenberry, 1967: 24).

Naturally, all Starfleet captains, as representatives of a hierarchical, semi-military service, which fulfills a role akin to the Royal Navy during the Golden Age of Sail, are constantly employed in political negotiations and they have to deal with a wide range of political entities. Their lack of intrinsic political ambitions and their meritocratic anxiety, however, comes to the fore in situations which lead to a possible promotion or transfer - even if it is only temporary - and thus away from their independent command. As Kirk tells Picard, as the captain of one Enterprise to that of another, 'don't let them promote you. Don't let them transfer you. Don't let them do anything that takes you off the bridge of that ship, because while you're there, you can make a difference' (Star Trek: Generations). Similarly, Captain Sisko is asked twice to temporarily assume a higher posting and, both times, he expresses reluctance upon accepting the assignment, and then repeatedly voices a yearning to return to his original command (ST:DS9 4.11, 'Homefront;' 4.12, 'Paradise Lost;' 6.04, 'Behind the Lines;' 6.05, 'Favor the Bold'). 
Volume 5, Issue 2

September 2012

Captain Janeway also advances in rank as evidenced her brief guest appearance as an admiral in Star Trek: Nemesis (2002), communicating a set of orders to Captain Picard. However, if the behavior of her future self, who put into motion a series of events which ultimately ensured the Captain's promotion to admiral, is any indication, then it may be safe to assume that, if there were any canonical continuation of Janeway's adventures, she would continue them as Captain.

The appeal of a captaincy, which is circumscribed by the self-contained habitats of their commands, is further indicated by a particular relationship pattern between them and their crews which is nurtured by their archetypal command culture. All Star Trek captains lead their crews in the vein of the romanticized Enlightenment mariner in that they lead by their judicious example and they form an archetypal Nelsonian "band of brothers (and sisters)," especially with their officers (cf. Roddenberry, 1987: 4).

\section{The finest crew in Starfleet: A perennial St. Crispin's Day}

As established in the previous section, the idealised Enlightenment mariner of the popular imagination is a 'mild hero,' someone who is perceived to be kinder and more just in the command over his subordinates than their contemporaries. Even though there is no longer any corporal punishment nor any other major physical hardship on Starfleet vessels, the set of behavioral patterns which make Hornblower a stern yet beloved, paternalistic captain, is maintained as the bedrock of the archetypal Starfleet captain. He fosters a command style which rests on a dialogic of delegation and open communication.

Nelson scholars agree that the Admiral's use of Shakespeare did not amount to much more than 'a few half-remembered quotations' but it is also documented that one of his favorite plays was Henry $V$ (Vincent, 2005: 75). Equally documented, and popularly remembered is Nelson's appropriation of one of those half-remembered lines from Henry's St. Crispin's Day Speech, which he gave before the Battle of Agincourt (1415) (cf. White, 2005: xv). Nelson appropriated the phrase 'band of brothers' to refer to his captains and the other officers under his command as a part of a command culture of clear communication, mutual encouragement and trust. With Hornblower being conceived in the vein of the Enlightenment mariner, once he has achieved a certain maturity of command, the narratives are replete with 'band of brothers' rhetoric (Forester, 1945: 210-211; Forester, 1946: 429-30; Forester, 1958: 574575). At the same time, he frantically tries to keep a critical distance to his officers, maintaining a mask of sternness, taciturnity and deliberate emotional detachment. Still, his crew respects him to a point of worship and the captain cannot help but form an intensely personal friendship with his long-term first lieutenant, later his flag captain, William Bush, and to take certain junior officers under his stringently nurturing wings.

In extrapolating a semi-military naval service, which is based on the Royal Navy of the popular imagination, Roddenberry simply transferred the positively connoted 'band of 
brothers' leadership style as another key characteristic of his archetypal starship captain. The way Starfleet captains command their crews and how they arrive at their decisions represents an exercise in extrapolative similitude to Hornblower. Though still cast in the vein of the benign 'man alone' paradigm, it is intermittently realised in deceptively democratic discourse. Still, once the captain has arrived at a decision, it is helpful, as Lt. Tuvok (Tim Russ) states, to "remember this guideline: "The captain is always right"' (ST:VOY 4.09, 'Year of Hell, Part II'). This is reminiscent of similar musings found among Hornblower's men; 'if Hornblower thought it right, it must be so, and there was no need to wonder about it" (Forester, 1938a: 524).

Maritime nostalgia serves, as it has already become apparent, as a continuous underpinning for the Starfleet captains. Captain Picard even goes so far as to explicitly re-enact one aspect of the Nelson Touch, explicitly invoking the Admiral. Before joining battle with the Borg, Picard and the Enterprise hide in a nebula. The captain records the following in his log: 'We continue to prepare our defenses for the inevitable confrontation, but I must admit, on this night I contemplate the distinct possibility that no defense may be adequate against this enemy' (ST:TNG 3.26, 'The Best of Both Worlds'). While we hear the voice-over, the captain is seen touring the ship on the lower decks, talking to ordinary crewmen, receiving their reports as he passes through the bowls of the ship. Ultimately, he arrives in Ten Forward, a lounge with sizable, forward-facing panorama windows, which at that point seems to be devoid of any patrons. Seeking respite, believing he is alone, Picard is startled by Guinan (Whoopi Goldberg), the barkeeper:

Guinan: Trouble sleeping?

Picard: Something of a tradition, Guinan. The Captain touring the ship before a battle. Guinan: Before a hopeless battle, if I remember the tradition correctly.

Picard: Not necessarily. Nelson toured the HMS Victory before Trafalgar. (Ibid.)

The ritualised performance of this maritime tradition serves as both a symbol for courage and hope regardless of the odds, and as yet another articulation of Starfleet captains' genealogical ancestry. Unlike Henry at Agincourt, and Nelson at Trafalgar, Picard does not win the battle with the Borg at first; but he eventually wins the war. The Captain repeats the ritual on the eve of another battle not only quoting himself but also implicitly invoking Nelson again. In Star Trek: Nemesis he records another log entry while he is shown touring his ship, rallying and comforting the crew with his very presence: 'The crew has responded with the dedication I've come to expect of them. And like a thousand other commanders on a thousand other battlefields, I wait for the dawn.' However, the Nelson Touch with its 'band of brothers' command paradigm amounts to more than just touring the ship before battle as it was supposedly done by the Admiral. Picard may have been the only captain to directly invoke Nelson but all principle Star Trek captains practice the full range of the Nelson Touch. 
Volume 5, Issue 2

September 2012

A 'band of brothers' moment usually takes the form of an officers' meeting; or, in more contemporary terms, a mission briefing. Commanders such as Nelson, Cook or Hornblower, would invite every officer, who it concerns, to the ship's great cabin where they would delineate the current situation and the impending mission/action. Rather than informing his officers of their decisions, and their plans how to execute them, they propose a general course of action and invite their officers' suggestions. A captain's goal is to draw on their expertise and insights as specialists in a collective of specialists in order to not only collect more information but also to check the ideas he harbors himself for flaws in logic. The captain would even allow for carefully-phrased criticism or objections. However, this is no democratic process because once the captain has listened to his officers' positions, and once he has reached his decision, the order is given and this is the last word. This process exemplifies the structural elements of the Nelson Touch as it rooted in 'personal warmth, hospitality, trust and... open sharing of information' (White, 2005: 54). The paradigm can be observed in almost any episode and movie of the Star Trek franchise.

The effect of similitude in re-enacting this maritime tradition is further enhanced by the space where those meetings take place. On the ships of wind and sail, meetings took place not on the quarterdeck (a place considered too public) but in the enclosed sanctum of the captain's great cabin. Though usually smaller in spatial terms than the descriptor 'great' might indicate, the cabin was located at the stern of the ship, opening to a seascape vista through a series of windows (cf. Parkinson, 2005: 17, 73, King, 2000: 64-65). When Starfleet captains retreat to hold counsel with their officers, they proceed to a room which is invariably referred to as briefing room, conference or observation lounge. Most of them are directly adjacent to the bridge and feature large panorama windows, which face out the stern of the ship. The rooms on the Enterprise- $A,-D,-E$, and on Voyager serve as particularly good examples. Set in an earlier period, the meeting rooms on the original Enterprise and the Enterprise NX-01 are not equipped with large-scale windows. On the other hand, Deep Space Nine's wardroom also opens up to a starry vista. Consequently, the discursive particularities and the sequential structure of the Nelson Touch as it is performed as an archetypal nautical tradition, is reenforced by a spatial similitude with wooden sailing vessels.

The recurrent set of behavioral/relationship patterns pertaining to the captain's second-incommand is also a distinct outgrowth of the Nelsonian command style as it is practiced by Hornblower. Forester's novels not only chart the picaresque career of his protagonist but also the evolving friendship and deep bond between him and his long-term second-in-command, William Bush. His seemingly terse and 'unexpected intimacy with Bush' is one of the few personal relationships that pierces 'his own faults of personality,' which usually prevent him from forming emotional attachments that are too elaborate according to his own judgment (Sternlicht, 1999: 107, Forester, 1998: 103). The fraternal/paternal bond between Hornblower and Bush, which is a result of the former's judiciousness as a 'mild hero,' provides the archetypal relationship pattern between all Star Trek captains and their first officers, who 
Volume 5, Issue 2

September 2012

were discursively re-imagined by Roddenberry as 'first lieutenants' in space (Roddenberry, 1964: 8; 1987: 24).

Even Roddenberry's earliest draft for Star Trek contains a character sketch titled 'the First Lieutenant,' who is conceived as 'the captain's right-hand man, the working level commander of all the ship's functions' (Roddenberry, 1964: 8). Roddenberry is fairly explicit as to the inspirational source for this character. In his guidelines for $S T: T N G$, the first officer of the Enterprise is generally referred to as 'Number One,' a term 'whose meaning has not changed appreciably since Earth's seventeenth century when the second-in-command of sailing ships became generally known as 'First Lieutenants' (hence Number One being used as the equivalent of First)' (Roddenberry, 1987: 24). The epithet 'Number One' had already been used by Captain Pike in 'The Menagerie.'

Apart from the hierarchical position and the field of shipboard duties, Roddenberry also establishes the same level of male Philia, which shapes Hornblower's relationship with Bush, as the archetypal norm between the starship captain and their first officers. Perpetually oscillating, like Hornblower, between fraternal and paternal articulations of their relationship, Star Trek's archetypal first officer may be read as a 'William Bush in space' even though it is nowhere explicitly stated. Even though the relationships between the captains and their second-in-commands in the later shows are increasingly accentuated by attempts on part of the writers to move beyond paternal/fraternal structures of male Philia, their base tone still carries the connotation of being as powerful as, and more often than not, more important than those of family. The first officers in Star Trek represent the most crucial node in the emotional bond which the captains forms with their surrogate families (their crews), as their situation is framed by perpetual isolation and detachment.

\section{The crucibles of the (wo)men alone}

So far, the Enlightenment mariner of the romantic imagination coming to life in Hornblower and, by extension, in the Star Trek captains, appears to be 'something of a supersailor' (Sternlicht, 1999: 113). However, one distinct character constraint of Hornblower takes shape in the form of his peculiar psychological struggle. It is determined by his incessant selfreflection, self-doubt and his anxiety over failing in his duty. It is further accentuated by a distinct lack of domestic happiness, which is largely due to his passion for remaining on independent commands, accompanied by the temptations of distant stations and the tinge of desire for his ships. A ship tends to be invested with nurturing qualities because it circumscribes the lives within its spatially encoded wooden limitations, protecting them from the vagaries of harsh natural environments. It also sustains the sexual connotations, which derive from a seemingly primal urge to possess a feminized entity in the absence of a human companion, ascribed to it by the master and commander of the ship. Forester dispassionately delineates Hornblower's psyche in the seemingly countless pages of internal monologue 
Volume 5, Issue 2

September 2012

which is focalised through the hero in the heterodiegetic narrative of the novels. The captain's

struggle would go on as long as he was to live, for it was the struggle with himself. He was self-critical. Just as no man is supposed to be a hero to his own valet, so Hornblower could not be a hero to his own self. He would be too cynical about his own motives, too aware of his own weaknesses, ever to know content. (Forester, 1998: 87-88)

The captain barely shows his internal struggle to anyone. He keeps a close guard on his emotions. However, since Hornblower is the focaliser in all but one of the novels, the readers are privileged, albeit sometimes overburdened with a steady stream of meticulously delineated self-criticism, self-loathing and anxious self-chastisement. While Hornblower's psychological struggles unfold in internal monologues, they are converted on Star Trek into a set of recognizable character behavior and character constellations. Each principle Starfleet captain usually has two people they confide in. One is always the captain's second-incommand. The second fixture in this character constellation is usually someone who the captain knows from a previous command or someone with whom they form a deep bond of trust via shared personal trials. The Captain's Log is an additional venue where the captains articulate their Hornblower-esque flaws and doubts.

In his sketch of the archetypal Starfleet captain, Roddenberry makes it unmistakably clear that even though his captain is 'lean and capable both mentally and physically,' his 'colorfully complex personality... lives a continual battle with self-doubt' (Roddenberry, 1964: 5). This aspect of the archetype found a pronounced articulation in Captain Pike, who is shown struggling with - and almost succumbing to - the tremendous strain caused by the responsibilities which he bears. Confiding in his doctor, Pike is deeply troubled over the loss of three crewmen, including his yeoman, for which he blames himself and the decisions he made. He even goes so far as to say that 'I'm tired of deciding... to the point of considering resigning' ('The Menagerie'). The archetype found its continued articulation in Captain Kirk, who remained someone who is 'constantly on trial with himself,' setting the norm for all Starfleet captains who followed (Roddenberry, 1967: 10). His desire to live a life of independent command occasionally takes its toll regardless of his crew's devotion and support for him; 'Kirk feels these responsibilities strongly and is fully capable of letting the worry and frustration lead him into error' (Ibid.). Similar to Hornblower, Kirk severely chastises himself when he does not live up to his self-imposed parameters of achievement and success as well as when something does not go according to plan.

Despite being considerably more experienced, Captain Picard 'has his share of idiosyncrasies' which betray his prudently shielded equanimity 'when deep emotions are triggered,' (Roddenberry, 1987: 23) - especially in the aftermath of being cybernetically violated by the Borg (ST:TNG 'The Best of Both Worlds'; 4.01, 'The Best of Both Worlds, 
Volume 5, Issue 2

September 2012

Part II;' 4.02, 'Family'). Captain Sisko, as a recipient of the devastation which constitutes Picard's trauma, ${ }^{9}$ is introduced as being full of self-doubt. Upon receiving his mission orders from Picard he states that he is 'investigating the possibility of returning to Earth for civilian service' (ST:DS9 1.01, 'Emissary'). However, he remains in command as he has found purpose and certainty by the end of the episode. Sisko faithfully re-enacts the archetypal behavior of maintaining a calm, placid and civil demeanor, but seriously taking himself to task when circumstances make him temporarily lose his temper or when he fails in his duty (ST:DS9 5.13, 'For the Uniform;' 6.13, 'Far Beyond the Stars;' 6.19, 'In the Pale Moonlight;' 6.26, 'Tears of the Prophets').

Captain Janeway's psychological turmoil stems from her relentless adherence to principles, and her self-imposed facade of imperturbability. It is the gravity of her decision to strand her own crew on the other side of the galaxy which provides ample opportunities for her to revisit and question her choices. Despite the fact that she could have never arrived at a different decision without defying the archetypal judiciousness of a Starfleet captain or, rather, because of it, it is her recurring doubts which make her develop considerable zeal for her new mission - to guide her family home. Whenever the survival of her crew does not require her utmost attention, the doubts about her decision come clearly to the fore. When Voyager finds itself in an interstellar void (a sector of space which is completely devoid of stars and planetary systems), the captain grows significantly despondent (ST:VOY 5.01, 'Night').

Jonathan Archer sets sail as the one captain who has, arguably, the most untroubled mind at the beginning of his mission. However, he quickly realises that his intuitive approach of making up rules as he goes along may require a significant revision once he sees the unexpected effects of decisions which he makes and/or which are forced upon him. He is then seen to slip into a despondent and melancholy mood, falling short of assuming a defeatist attitude (ST:ENT 1.26, 'Shockwave'). Ultimately, he clearly follows the 'man alone' paradigm as he begins to feel the 'weight of the world... Literally,' (ST:ENT 2.26, 'The Expanse') in the wake of a devastating attack on the Earth.

Hornblower's fallibility is not just limited to his psychological struggle, but extends to his dealings with the opposite sex. This is yet another component which became a mainstay for all principle Starfleet captains along with their respective internal struggles. Hornblower's preferred naval lifestyle inevitably leads to a distinct lack of domestic happiness. This is evidently cast in the vein of the Nelson-Hamilton affair which has been arduously and brazenly popularized and revisited for two hundred years (Czisnik, 2005: 55-80). Forester succinctly describes his hero as 'the sort of man with whom any woman might fall deeply in love, and yet whom a discerning or intuitive woman would recognize as one neither to hold nor to bind' (Forester, 1998: 100).

Accurately following the same character constraints of Hornblower, Kirk, when 'away from the confines of self-imposed discipline,' is prone to enter 'at one time or another into an 
Volume 5, Issue 2

September 2012

unwise romantic liaison which he will have great difficulty disentangling' (Roddenberry, 1964,: 5). Even though Kirk undoubtedly has a reputation as a "ladies' man," this does not alleviate his lack of domestic happiness. The only relationship which bore a certain degree of promise not only fails, but its aftermath exacerbates his domestic (un)happiness when his son is killed (Star Trek II: The Wrath of Khan (1982), Star Trek III: The Search for Spock (1984)). Also following the character constraints of the Hornblower archetype, it becomes clear that the loneliness of command may only be alleviated by a captain's band of brothers, and that 'the antidote to a woman... is a starship' (ST:TOS 3.13, 'Elaan of Troyius').

Making it explicit that he is cast along the same Hornblower-esque lines, Roddenberry simply states that Picard 'has gone the way we saw Kirk going, content with a "starship love" (Roddenberry, 1987: 23). Captain Sisko is quite possibly the most tormented captain when it comes to the domestic sphere. He is introduced as a family man, but his wife, Jennifer (Felicia Bell), is killed in the first ten minutes of ST:DS9's pilot episode, leaving him to care for his son alone. Sisko's domestic (un)happiness 'is still very much a life framed by tragedy' as it is revealed over the course of seven seasons (Berman et al., 1992: 8). After a series of potential love affairs fail to progress beyond even the earliest of stages, a more permanent romantic interest presents itself in freighter captain Kasidy Yates (Penny Johnson), but even this relationship is fraught with disappointment. Firstly, he has to arrest her for smuggling and she serves time in prison (ST:DS9 4.22, 'For the Cause'). Once she is back on the station, the promise of a content family life is cut short due to Sisko's predetermined role as a spiritual 'Emissary,' as he is whisked away onto a higher plane of existence, leaving his pregnant wife behind (ST:DS9 7.25, 'What You Leave Behind').

Michèle Barrett argues that 'Captain Janeway's situation resembles nothing in eighteenth- or nineteenth-century fiction' (Barrett, 2001: 11). Yet, Janeway adheres to every aspect of the composite Enlightenment mariner, which includes finding herself at the most distant station where the archetypal lack of domestic happiness holds particularly true. It is her singular zeal to keep travelling and return home which make it impossible for her to achieve any meaningful domestic happiness outside the band of brothers paradigm. Engaged to a man when Voyager is hurled 70,000 light-years across the galaxy, she has little chance of ever seeing him again. After some time, contact with home is established and she learns that her fiancé has abandoned hope and has married someone else (ST:VOY 4.15, 'Hunters'). Once freed from her obligations, the captain hesitatingly pursues a handful of romantic encounters with transient aliens and holographic phantasms (ST:VOY 5.10, 'Counterpoint;' 6.11, 'Fair Haven;' 7.16, 'Workforce;' 7.17, 'Workforce, Part II'). Ultimately, she adheres to the Hornblower-esque formula in order to protect her surrogate family - her crew of interstellar maritime voyagers.

Captain Archer does not add much substance or variation to Hornblower's archetypal lack of domestic happiness. The captain's life of restless adventures is not entirely devoid of romantic entanglements (ST:ENT 1.09, 'Civilization;' 1.25, 'Two Days and Two Nights;' 3.04, 'Rajiin;' 4.01, 'Storm Front;' 4.02, 'Storm Front, Part II'). However, they all occur in 
Volume 5, Issue 2

September 2012

passing since he is eager to make 'history with every lightyear' he travels (ST:ENT 1.03, 'Fight or Flight').

Thus all these captains are restless wanderers in their desire to remain in command of a ship which they sail to the most distant stations in the transoceanic seascapes of outer space. Desirable as it may be for them, their geographic transience takes its toll, as being a Hornblower-esque "fighting naturalist" in space precludes peace of mind and domestic happiness.

\section{Conclusion}

This article serves to demonstrate that Star Trek's intrepid starship captains are not space cowboys, riding off into the starry horizons of Star Trek's final frontier. Instead, they sail the ocean of outer space, much like the idolised and idealised seafaring captains of Romantic thought - the Nelson(s) and Cook(s) of popular myth. Not since the Golden Age of Sail has a ship captain held so many different responsibilities, performed such a diverse range of functions, or acted so independently and out of touch with their superior officers. Then again, the future according to Star Trek is distinctively reminiscent of the late 18th century when British ships purportedly ruled the waves (cf. Roddenberry, 1967: 23, Whitfield and Roddenberry, 1991: 179, Gerrold, 1973: 11). As the officers of the Royal Navy were the vectors of a supposedly enlightened imperial project, so the Starfleet captains perform a similar role in the 22nd, 23rd and 24th centuries. Not only does Hornblower serve as an omnipresent (whether explicit or implied) reference point for the Starfleet captains, but he also provides telling evidence that establishes an irrefutable link to the British Golden Age of Sail as much as it stresses a transatlantic continuity in Star Trek. The captains are the central node in Star Trek's transatlantic maritime endowment which amounts to a historicised/historiographic telling of its narratives.

All of the captains adhere to the same archetypal model. They find themselves on detached service with a broad set of orders, containing exploratory, defensive and diplomatic objectives. They are left to rely only on their own judgment, bearing all responsibility despite the counsel and support they receive from their officers and crews. They also have a distinct propensity to critically question their orders and they usually go beyond their original mission objectives. Even though they are respected, and even adored by their subordinates, their enormous responsibilities leave a deep imprint of introspection and doubt on their psyche, making them fallible on occasion. Still, they excel at most of what they do and this earns them recognition and success which paradoxically threaten to take them away from their migratory life of restlessness. This has left them with a string of broken relationships, amorous affairs and a distinct lack of domestic happiness. The love for their starship and a deep, paternal friendship with their second-in-command are their only consolatory constants. 
Volume 5, Issue 2

September 2012

These are the 'Hornblowers in space' as they emerge from the series' bibles, the episodes and the movies. The fact that C. S. Forester conceived Hornblower not just as a British hero, but as a distinct transatlantic protagonist bears additional weight in the light of Star Trek's transatlantic maritime endowment (Sternlicht, 1999: 16). And, even while astronauts of the early U.S. space program, which formed the immediate context of Star Trek's creation, were recruited from the air wings of the U.S. Armed Forces, Roddenberry, himself a pilot, would still re-imagine his future spacefarers as naval officers of the Golden Age of Sail. As the descriptive model used by Roddenberry, Forester's transatlantic hero, who is an articulation of the Nelsonian hero of Romantic thought, has emerged as being more than simple television shorthand. He bestows his character traits, constraints and peculiarities onto all principal Star Trek captains as the archetype which allows these captains to be both maritime warriors and maritime explorers in space; sailing as 'fighting naturalists' in outer space.

\section{References}

Abbott, C. (2006) Frontiers past and future: Science fiction and the American West. Lawrence: University Press of Kansas.

Alexander, D. (1994) Star Trek Creator: The Authorized Biography of Gene Roddenberry. New York: Penguin Books.

Barrett, M. and Barrett, D. (2001) Star Trek: The Human Frontier. Cambridge: Polity Press.

Berman, R. and Piller, M. (1992, June 12) Star Trek DS9 Bible. Unpublished manuscript.

Berman, R. et al. (1995) Star Trek Voyager Bible. Unpublished manuscript.

Berman, R. et al. (2001) Star Trek Enterprise Bible. Unpublished manuscript.

Black, J. (2004) The British Seaborne Empire. New Haven: Yale University Press.

Conway, S. (2007) 'Empire, Europe and British Naval Power' in Cannadine. D (Ed.) Empire, the Sea, and Global History: Britain's maritime World. Basingstoke: Palgrave Macmillan, pp.22-40.

Czisnik, M. (2005) Horatio Nelson: A Controversial Hero. London: Hodder Education.

Edwards, P. (Ed.) (2003) James Cook, The Journals. London: Penguin Books.

Fernández-Armesto, F. (2007) 'Britain, the Sea, the Empire, the World' in Cannadine, D. (Ed.). Empire, the Sea, and Global History: Britain's maritime World. Basingstoke: Palgrave Macmillan, pp.6-21.

Fernández-Armesto, F. (2006) Pathfinders: A Global History of Exploration. New York: W.W. Norton \& Company.

Forester, C.S. (1937) The Happy Return. London: Michael Joseph.

Forester, C.S. (1938) Ship of the Line. London: Michael Joseph. 
Volume 5, Issue 2

September 2012

Forester, C.S. (1938b) Flying Colours. London: Michael Joseph.

Forester, C.S. (1945) The Commodore. London: Michael Joseph.

Forester, C.S. (1946) Lord Hornblower. London: Michael Joseph.

Forester, C.S. (1950) Mr. Midshipman Hornblower. London: Michael Joseph.

Forester, C.S. (1952) Lieutenant Hornblower. London: Michael Joseph.

Forester, C.S. (1953) Hornblower and the Atropos. London: Michael Joseph.

Forester, C.S. (1958) Hornblower in the West Indies. London: Michael Joseph.

Forester, C.S. (1987) Captain Hornblower R.N. London: Penguin Books.

Forester, C.S. (1996) Admiral Hornblower. London: Penguin Books.

Forester, C.S. (1998 [1964]) The Hornblower Companion. London: Chatham Publishing.

Forester, C.S. (1998) The Young Hornblower Omnibus. London: Penguin Books.

Forester, J. (1997) 'Father’s Tales,' The American Scholar, 66 (4), pp.533-545.

Fulford, T. (1999) 'Romanticizing the Empire: The Naval Heroes of Southey, Coleridge, Austen, and Marryat,' Modern Language Quarterly: A Journal of Literary History, 60 (2), pp.161-196.

Geraghty, L. (2007) Living with Star Trek, American Culture and the Star Trek Universe. New York: I.B. Tauris.

Gerrold, D. (1973) The World of Star Trek. New York: Ballantine Books.

Gregg, S. (Ed.) (2005) Empire and Identity: An eighteenth century sourcebook. Basingstoke: Palgrave Macmillan.

Harris, J. (2006) “"Domestic Virtues and National Importance:” Lord Nelson, Captain Wentworth, and the English Napoleonic War Hero,' Eighteenth-Century Fiction, 19 (1-2), pp.181-205.

King, D. (2000) A Sea of Words: A Lexicon and Companion to the complete seafaring tales of Patrick O'Brian. New York: Holt Paperbacks.

Lamb, J. (2006) 'Cook and the Question of Naval history,' Eighteenth-Century Life, 30 (2), pp.98-115.

Lambert, A. (2004) 'Retracing the Captain: "Extreme History," hard tack and scurvy' in Williams, G. (Ed.) Captain Cook: Explorations and Reassessments. Suffolk: The Boydell Press, pp.246-255.

McCurdy, H. (1997) Space and the American Imagination. Washington, D.C.: Smithsonian Institute Press.

Monteith, S. (2008) American Culture in the 1960s. Edinburgh: Edinburgh University Press. 
Volume 5, Issue 2

September 2012

O'Sullivan, D. (2008) In the search of Captain Cook: Exploring the man through his own words. New York: I.B. Tauris.

Parkinson, C. (2005 [1949]) Portsmouth Point, The Navy in Fiction 1793-1815. Liverpool: Liverpool University Press.

Price, A. (1992) The Eyes of the Fleet, A popular history of frigates and frigate captains 1793-1815. London: HarperCollins.

Parrill, S. (2009) Nelson's Navy in Fiction and Film. Jefferson: McFarland \& Company.

Rabitsch, S. (2011) 'Wagon Train to the stars - Star Trekkin' the U.S. western frontier' in Rio, D. and Ibarraran, A. (Eds.) Beyond the Myth: New Perspectives on Western Texts. Vitoria-Gasteiz: PortalEducation, pp.177-204.

Rayner, J. (2007) The Naval War Film: Genre, History, National Cinema. Manchester: Manchester University Press.

Roddenberry, G. (1964, March 11) 'Star Trek is...' Ex-Astris Scientia. http://www.ex-astrisscientia.org/misc/40_years/trek_pitch.pdf [accessed 2012, August 12].

Roddenberry, G. (1967, April 17) The Star Trek Guide. Third Revision. Unpublished manuscript.

Roddenberry, G. (1987, March 23) Star Trek: The Next Generation Writer/Director's Guide. Unpublished manuscript.

Sternlicht, S. (1999 [1981]) C.S. Forester and the Hornblower Saga. Revised Edition. Syracuse: Syracuse University Press.

White, C. (Ed.) (2005) Nelson: The New Letters. Woodbridge: The Boydell Press.

Whitfield, S. and Roddenberry, G. (1991 [1968]) The Making of Star Trek. London: Titan Books.

Williams, G. (2008) The Death of Captain Cook - A hero made and unmade. Cambridge: Harvard University Press.

Williams, G. (2004) “"As befits our age, there are no more heroes:” reassessing Captain Cook' in Williams, G. (Ed.) Captain Cook: Explorations and Reassessments. Suffolk: The Boydell Press, pp. 230-245

Vincent, E. (2005) 'Nelson the man' in Stilwell, A. (Ed.) The Trafalgar Companion. Oxford: Osprey Publishing, pp.61-81.

Vincent, E. (2005) 'Nelson the commander' in Stilwell, A. (Ed.) The Trafalgar Companion. Oxford: Osprey Publishing, pp.83-101.

Yoggy, G. (1996) 'Prime-Time Bonanza! The Western on Television' in Aquila, R. (Ed.) Wanted dead or alive: the American west in popular culture. Champaign: University of Illinois Press, pp.160-186. 
Volume 5, Issue 2

September 2012

\section{Teleography}

Captain James Cook. (1987) Australia/West Germany/France/Spain: Revcom Television/ Norddeutscher Rundfunk/Australian Broadcasting Corporation/Resolution/Griffin/Radio Television Español/Galaxy Film.

I Remember Nelson. (1982) U.K.: Central Television.

Star Trek. (1966-1969) U.S.A.: Desilu Productions/Paramount Television/Norway Corporation.

- 'The Menagerie' aka. 'The Cage,' Star Trek. Episode 1.00. Dir. Robert Butler. NBC. 1988, October 4.

- 'Spectre of the Gun,' Star Trek. Episode 3.06. Dir. Vincent McEveety. NBC. 1968, October 25.

- 'Elaan of Troyius,' Star Trek. Episode 03.13. Dir. John Meredyth Lucas. NBC. 1968, December 20.

Star Trek: The Animated Series. (1973-1974) U.S.A.: Filmation Associates/Norway Productions/Paramount Television.

- 'The Counter-Clock Incident,' Star Trek: The Animated Series. Episode 2.06. Dir. Bill Reed. NBC. 1974, October 12.

Star Trek: The Next Generation. (1987-1994) U.S.A.: Paramount Television.

- 'The Best of Both Worlds,' Star Trek: The Next Generation. Episode 03.26. Dir. Cliff Bole. 1990, June 18.

- 'The Best of Both Worlds, Part II,' Star Trek: The Next Generation. Episode 4.01. Dir. Cliff Bole. 1990, September 24.

- 'Family,' Star Trek: The Next Generation. Episode 4.02. Dir. Les Landau. 1990, October 1.

- 'Time's Arrow,' Star Trek: The Next Generation. Episode 5.26. Dir. Les Landau. 1992, June 15.

- 'Time's Arrow, Part II,' Star Trek: The Next Generation. Episode 6.01. Dir. Les Landau. 1992, September 21.

- 'A Fistful of Datas,' Star Trek: The Next Generation. Episode 6.08. Dir. Patrick Stewart. 1992, November 9.

Star Trek: Deep Space Nine. (1993-1999) U.S.A: Paramount Television.

- 'The Emissary,' Star Trek: Deep Space Nine. Episode 1.01. Dir. David Carson. 1993, January 3. 
Volume 5, Issue 2

September 2012

- 'Homefront,' Star Trek: Deep Space Nine. Episode 4.11. Dir. David Livingston. 1996, January 1.

- 'Paradise Lost,' Star Trek: Deep Space Nine. Episode 4.12. Dir. Reza Badiyi. 1996, January 8 .

- 'For the Cause,' Star Trek: Deep Space Nine. Episode 4.22. Dir. James L. Conway. 1996, May 6.

- 'Trials and Tribble-ations,' Star Trek: Deep Space Nine. Episode 5.06. Dir. Jonathan West. 1996, November 4.

- 'For the Uniform,' Star Trek: Deep Space Nine. Episode 5.13. Dir. Victor Lobi. 1997, February 3.

- 'Behind the Lines,' Star Trek: Deep Space Nine. Episode 6.04. Dir. Levar Burton. 1997, October 20.

- 'Favor the Bold,' Star Trek: Deep Space Nine. Episode 6.05. Dir. Winrich Kolbe. 1997, October 27.

- 'Far Beyond the Stars,' Star Trek: Deep Space Nine. Episode 6.13. Dir. Avery Brooks. 1998, February 11.

- 'In the Pale Moonlight,'Star Trek: Deep Space Nine. Episode 6.19. Dir. Victor Lobi. 1998, April 15.

- 'Tears of the Prophets,' Star Trek: Deep Space Nine. Episode 6.26. Dir. Allan Kroeker. 1998, June 17.

- 'What You Leave Behind,' Star Trek: Deep Space Nine. Episode 7.25. Dir. Allan Kroeker. 1999, June 2.

Star Trek: Voyager. (1995-2001) U.S.A: Paramount Television.

- 'Flashback,' Star Trek: Voyager. Episode 3.02. Dir. David Livingston. UPN. 1996, September 11.

- 'Year of Hell, Part II,' Star Trek: Voyager. Episode 4.09. Dir. Mike Vejar. UPN. 1997, November 12.

- 'Hunters,' Star Trek: Voyager. Episode 4.15. Dir. David Livingston. UPN. 1998, February 11.

- 'Night,' Star Trek: Voyager. Episode 5.01. Dir. David Livingston. UPN. 1998, October 14.

- 'Counterpoint,' Star Trek: Voyager. Episode 5.10. Dir. Les Landau. UPN. 1998, December 16. 
Volume 5, Issue 2

September 2012

- 'Fair Haven,' Star Trek: Voyager. Episode 6.11. Dir. Allan Kroeker. UPN. 2000, January 12.

- 'Workforce,' Star Trek: Voyager. Episode 7.16. Dir. Allan Kroeker. UPN. 2001, February 21.

- 'Workforce, Part II,' Star Trek: Voyager. Episode 7.17. Dir. Roxann Dawson. UPN. 2001, February 28.

Star Trek: Enterprise. (2001-2005) U.S.A.: Paramount Television/Rick Berman

Productions/Braga Productions.

- 'Fight or Flight,' Star Trek: Enterprise. Episode 1.03. Dir. Allan Kroeker. UPN. 2001, October 3.

- 'Civilization,' Star Trek: Enterprise. Episode 1.09. Dir. Michael Vejar. UPN. 2001, November 14.

- 'Two Days and Two Nights,' Star Trek: Enterprise. Episode 1.25. Dir. Michael Dorn. UPN. 2002, May 15.

- 'Shockwave,' Star Trek: Enterprise. Episode 1.26. Dir. Allan Kroeker. UPN. 2002, May 22.

- 'The Expanse,' Star Trek: Enterprise. Episode 2.26. Dir. Allan Kroeker. UPN. 2003, May 21.

- 'Rajiin,' Star Trek: Enterprise. Episode 3.04. Dir. Michael Vejar. UPN. 2003, October 1.

- 'North Star,' Star Trek: Enterprise. Episode 3.09. Dir. David Straiton. UPN. 2003, November 12.

- 'Storm Front,' Star Trek: Enterprise. Episode 4.01. Dir. Allan Kroeker. UPN. 2004, October 8.

- 'Storm Front, Part II,' Star Trek: Enterprise. Episode 4.02. Dir. David Straiton. UPN. 2004, October 15.

Wagon Train. (1957-1965) U.S.A.: Universal TV/Revue Studios.

\section{Filmography}

Master and Commander: The Far Side of the World. (2003) Dir. Peter Weir. U.S.A.:

Twentieth Century Fox Film Corporation/Universal Pictures/Miramax Films/Samuel Goldwyn Films.

The Nelson Affair. (1973) Dir. James Cellan Jones. U.K.: Hal Wallis Productions.

Star Trek II: The Wrath of Khan. (1982) Dir. Nicholas Meyer. U.S.A.: Paramount Pictures. 
Volume 5, Issue 2

September 2012

\title{
Star Trek III: The Search for Spock. (1984) Dir. Leonard Nimoy. U.S.A.: Paramount
} Pictures/Cinema Group Ventures.

\author{
Star Trek IV: The Voyage Home. (1986) Dir. Leonard Nimoy. U.S.A.: Paramount \\ Pictures/Industrial Light \& Magic.
}

Star Trek: Generations. (1994). Dir. David Carson. U.S.A.: Paramount Pictures.

Star Trek: Nemesis. (2002) Dir. Stuart Baird. U.S.A.: Paramount Pictures.

Star Trek. (2009) Dir. J.J. Abrams. U.S.A.: Bad Robot/Paramount Pictures/Spyglass Entertainment/MavroCine Pictures GmbH \& Co. KG.

That Hamilton Woman. (1941) Dir. Alexander Korda. U.K.: London Film

Productions/Alexander Korda Films.

\footnotetext{
1 "Star Trek" refers to the entirety of the Star Trek franchise (1966- ). Henceforth, the following abbreviations will be used when individual series are discussed: ST:TOS for Star Trek: The Original Series (1966-1969), ST:TAS for Star Trek: The Animated Series (1973-1974), ST:TNG for Star Trek: The Next Generation (19871994), ST:DS9 for Star Trek: Deep Space Nine (1993-1999), ST:VOY for Star Trek: Voyager (1995-2001), and ST:ENT for Star Trek: Enterprise (2001-2005).

${ }^{2}$ Though certainly relevant for their elaborations, licensed as well as unlicensed novels published as part of Star Trek's ever-growing universe are generally not considered canonical. The canon of the Star Trek continuum is formed by the live-action television shows and the motion pictures.

${ }^{3}$ During the Golden Age of Sail, officers of the Royal Navy were employed in the fashion of true renaissance men as reputable soldiers, bold tacticians, diplomatic envoys, clever trade negotiators, adept engineers, meticulous mapmakers, enthusiastic naturalists, ambitious astronomers and, most importantly, as vectors of an Anglophone cultural hegemony (cf. Black, 2004: 166-170, Conway, 2007: 23).

${ }^{4}$ Patrick O'Brian's is largely considered to be C. S. Forester's successor who continued to popularise Napoleonic sea stories in the second half of the $20^{\text {th }}$ century. Even though O'Brian seems to have been clearly influenced by Forester, he repeatedly attacked and criticized Forester's Hornblower novels (Parill, 2009: 4, 6484, 163-189).

${ }^{5}$ ST:TAS 2.06, 'The Counter-Clock Incident.' In his short appearance, Captain April articulates at least two of the archetype's attributes - taking the initiative of command and the bond which a captain has with his ship. The author acknowledges that there is an on-going debate over whether ST:TAS can be considered part of Star Trek canon, but this incident is mentioned in the interests of completeness.

${ }^{6}$ The character of Captain Pike reappears in J.J. Abrams's feature film re-boot Star Trek (2009), portrayed by Bruce Grenwood. However, the Abrams-universe will not be drawn on for this article since it seems to have moved away from the Hornblower-esque nautical endowment envisioned by Roddenberry.

7 'Those who merit it shall bear the palm' (Czisnik, 2005: 8).

${ }^{8}$ In total, the Hornblower series comprises ten novels, one unfinished novel and five short stories which were all published between 1937 and 1967, some of them posthumously. C. S. Forester died in 1966, only a few months before $S T: T O S$ went on air.

${ }^{9}$ When Captain Picard was assimilated by the Borg, Starfleet sent a fleet to intercept the Borg ship. Drawing on Picard's knowledge of the battle plans, the Borg had no trouble defeating the fleet. Captain Sisko was on board one of the ships lost in the battle. Not only did he lose the ship he served on, but also most of his fellow crew mates, including his captain and, most importantly, his wife, Jennifer (Felecia Bell).
} 